\title{
PENGEMBANGAN PEGAWAI \\ MELALUI LATIHAN DAN PENDIDIKAN
}

\section{Oleh :}

\section{Saliman}

\section{Abstrak}

Penerimaan pegawai baru pada suatu lembaga tidak dapat menjamin akan diperolehnya pegawai yang siap melaksanakan pekerjaan, karena pada dasarnya tidak ada lembaga pendidikan yang menghasilkan lulusan siap kerja. Perputaran karyawan menyebabkan adanya kecanggungan karyawan untuk mengerjakan pekerjaannya di tempat yang baru. Dengan demikian perlu kegiatan untuk menjembatani dua permasalahan tersebut agar karyawan baru atau karyawan yang ditempatkan pada tempat baru dapat bekerja sesuai dengan tugasnya. Kegiatan tersebut dikenal dengan istilah latihan dan pendidikan pegawai.

Kegiatan pengembangan pegawai melalui latihan dan pendidikan dirancang dalam rangka mempersiapkan pegawai baru, supaya lebih siap melaksanakan pekerjaan, atau diselenggarakan dalam rangka mengembangkan karyawan lama supaya lebih mampu mengembangkan potensinya.

Ada beberapa teknik latihan dan pendidikan, namun untuk menentukan teknik yang paling efektif perlu ada penyesuaian-penyesuaian dengan kondisi lembaga penyelenggara. Pada akhirnya harus dilakukan kegiatan evaluasi untuk mengukur efektivitas latihan dan pendidikan tersebut.

\section{Pendahuluan}

Proses awal dan sangat menentukan dalam bidang kepegawaian adalah recruitment pegawai, yang dalam hal ini adalah memilih atau menyeleksi pegawai yang terbaik untuk setiap jabatan dan jenis tugas pada suatu lembaga. Selanjutnya melatih serta mendidik pegawai agar dapat melaksanakan tugas yang diembannya dengan baik. Hal ini penting, mengingat tidak seorangpun mampu melaksanakan tugas dengan 
baik dan lancar tanpa mengetahui jenis dan sifat pekerjaan yang dihadapinya. Bahkan untuk jenis pekerjaan yang bersifat sederhanapun tidak jarang seseorang mengalami kesulitan untuk melaksanakannya dengan baik dan lancar. Oleh sebab itu latihan dan pendidikan pegawai sangat perlu dilakukan terutama bagi pegawai baru yang belum mempunyai pengalaman.

Dalam Undang-undang No. 8 Tahun 1974 tentang Pokok-Pokok Kepegewaian disebutkan adanya dua jenis latihan dan pendidikan pegawai yaitu pre service training (latihan prajabatan) dan in service training (latihan dalam jabatan). Latihan prejabatan adalah suatu latihan yang diberikan kepeda pegawai baru agar mereka trampil dalam melaksanakan ugas yang diberikan kepadanya. Sedangkan latihan dalam jabatan edalah suatu latihan yang diberikan kepada pegawai guna meningkatkan keahlian, kemampuan atau ketrampilannya agar diperoleh produktivitas kerja yang tinggi.

\section{Yoder (1964) menyatakan}

bahwa latihan dapat membantu stabilitas pegawai serta mendorongnya untuk memberikan jasanya dalam waktu yang lebih lama. Sedangkan Taylor dalam Soedjadi (1977:47) mengenai penarikan pegawai menjelaskan bahwa salah satu tugas manejemen (duties of management) ialah karyawan yang terbaik untuk setiap tugas tertentu, untuk selanjutnya melatih dan mendidiknya. Di samping latihan dapat menambah pengetahuan dan ketrampilan pegawai juga dapat memberikan kepuasan psikologis kepada para pegawai, mengingat faktor manusia dalam organisasi sangat penting. Dalam fal ini melalui latihan dan pendidikan, para pegawai akan lebih memahami maksud, tujuan serta tugas pokok organisasi. Dengan demikian mereka akan lebih menaruh minat dan perhatian pada bidang pekerjaan masing-masing.

\section{Manfaat Latihan dan Pendidikan}

Menurut Hani Handoko (2000:103) ada dua tujuan utama program latihan dan pendidikan atau pengembangan pegawai. Pertama, latihan dan pengembangan dilakukan untuk menutup "gap" antara kecakapan atau kemampuan karyawan dengan permintaan jabatan. Kedua, program -program tersebut diharapkan dapat meningkatkan efisiensi dan efektivitas kerja karyawan dalam mencapai sasaran kerja yang telah ditetapkan. Sesuai dengan analisis jabatan, recruitment pegawai mensyaratkan mereka yang diterima sudah mempunyai kualifikasi tertentu. Namun karena lembaga pendidikan formal tidak mempersiapkan tenaga kerja siap pakai dan siap kerja pada lembaga tertentu, maka latihan pendidikan perlu diadakan oleh lembaga yang bersangkutan. Dalam hal ini latihan dan pendidikan berfungsi untuk men- 
jembatani kesenjangan antara kemampuan individu dengan kebutuhan pekerjaan di suatu lembaga.

Meskipun usaha-usaha latihan dan pendidikan memakan waktu dan mahal, akan tetapi manfaatnya besar sekali terhadap keberlangsungan lembaga, karena akan mengurangi perputaran tenaga kerja dan membuat karyawan menjadi lebih produktif dan professional. Lebih lanjut, latihan dan pendidikan membantu karyawan dalam menghindarkan diri dari keusangan dan melaksanakan pekerjaan dengan baik. Di samping latihan awal, orientasi kerja juga harus diberikan kepada pegawai baru. Hal ini didasarkan pertimbangan, bahwa sebelum bekerja mereka perlu diperkenalkan kepada pimpinan, rekan sekerja, lingkungan kerja, jenis-jenis pekerjaan yang akan segera dijalani, perlatan yang digunakan, struktur organisasi dan fungsi masing-masing bagian. Dengan demikian pegawai tersebut tidak akan merasa canggung untuk beradaptasi dengan dunianya.

Lebih jauh Wursanto (2001: 60) menjelaskan tentang manfaat la- tihan dan pendidikan sebagai berikut: (1) latihan dan pendidikan meningkatkan stabilitas pegawai; (2) latihan dan pendidikan dapat memperbaiki cara kerja pegawai, sehingga cara kerja mereka tidak bersifat statis melainkan selalu disesuaikan dengan perkembangan organisasi dan volume kerja; (3) dengan latihan dan pendidikan pegawai dapat berkembang dengan cepat; (4) dengan latihan dan pendidikan pegawai mampu bekerja lebih efisien; (5) dengan latihan dan pendidikan pegawai mampu melaksanakan tugas dengan lebih baik; (6) dengan latihan dan pendidikan berarti pegawai diberi kesempatan untuk mengembangkan diri; (7) latihan dan pendidikan meningkatkan semangat kerja pegawai dan produktivitas perusahaan.

Davis dan Westher dalam Bambang Suyono (1993:6), memberikan ilustrasi tentang keseimbangan antara kemampuan pegawai baru dengan lembaga setelah orientasi dan latihan, sebagai berikut: 


\section{Kemampuan Orientasi Latihan Kebutuhan Pegawai Baru Pekerjaan}
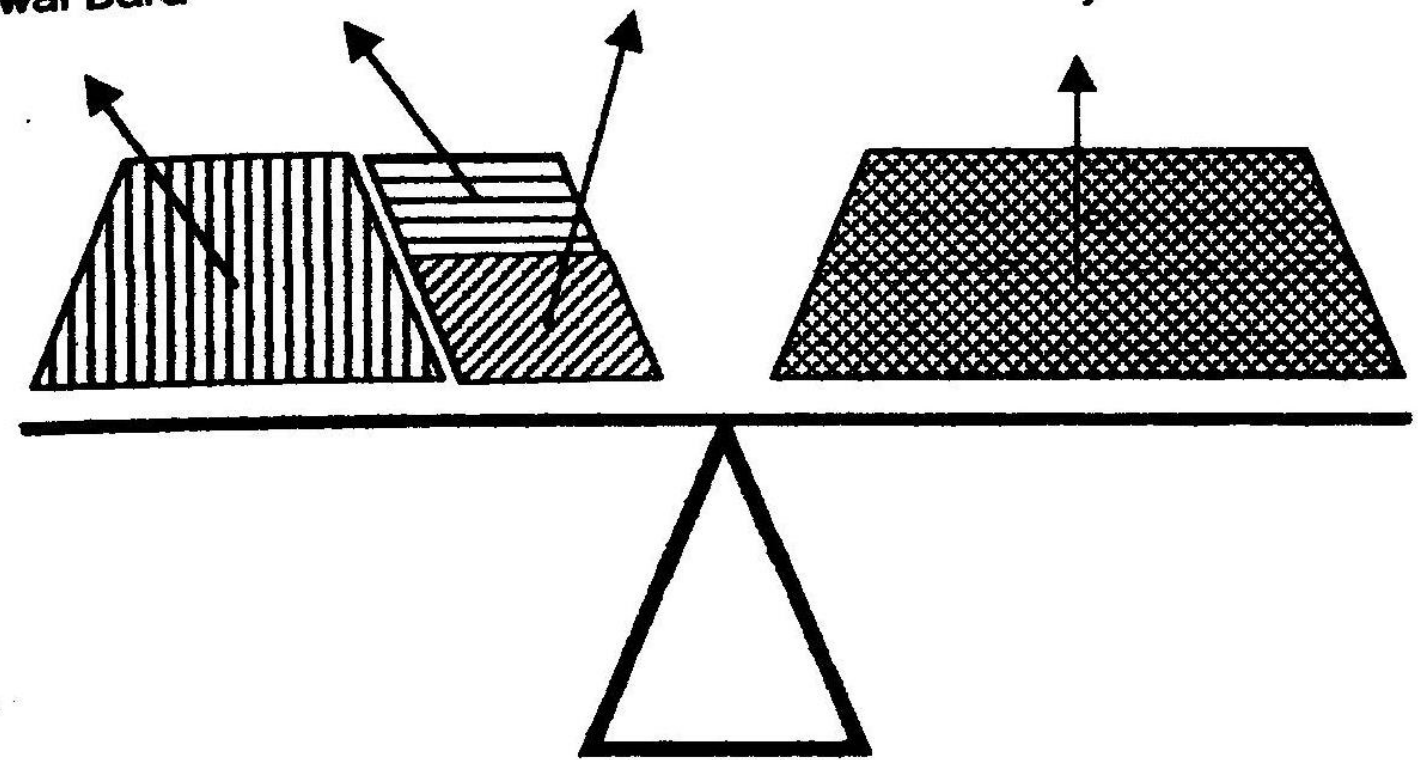

Gambar di atas, menjelasken bahwa orientasi dan latihan bagi pegewai sangat dipertukan agar kesenjengan antara kemempuan yang dimiliki pegawai baru dengan kebutuhan lembaga dapat diatasi. Hal ini berdasarkan pertimbangan, bahwa kemampuan individu dalam melakukan kerjasama untuk melaksanaken pekerjaan belum memberiken hasil yeng memuaskan sesuai dengan tujuan lembaga. Sekalipun Lembaga pendidikan dapat merekrut dan memilih personil yang terbaik, akan tetapi setelah lulusannya disuruh bekerja dengan sunguhsungouh sesuai dengan posisi yang diberikan dan dengan siapa harus bekerja, mereka tidak dapat memberiken hasil sesuai dengan harap- an lembaga. Guna mengatasi hal tersebut di atas, maka perlu diadakan orientasi terhadap pegawai baru yang dalam Undang-Undang No. 8 Tahun 1974, dikenal dengan Latihan Prajabatan. Latihan yang diberikan merupakan salah satu cara yang efektif untuk meminimalkan problema yang dihadapi, sehingga mereka dapat didorong untuk bekerja secara maksimal sesuai dengan tugas yang diberikan lembaga. Dengan latihan yang efektif dapat mendorong pegawai berasimilasi dengan lingkungan lembaga. Uraian di atas menunjukkan bahwa orientasi tidak hanya penting bagi pegawai, tetapi juga bagi lembaga yang bersangkutan. Bagi lembaga, latihan merupakan investasi dalam bentuk sumber daya ma- 
nusia yang manfaatnya akan tampak dalam jangka waktu yang lama.

Menurut Davis dan Werther dalam Bambang Suyono (1993:7) tentang keuntungan dari latihan dan pendidikan dapat dilihat dari beberapa sudut pandang, yaitu dari sisi lembaga perekrut pegawai, bagi individu pegawai yang bersangkutan, dan bagi hubungan antar individu dan kelompok dalam lembaga yang bersangkutan.

\section{Keuntungan bagi lembaga}

Bagi lembaga, keuntungan latihan dan pendidikan adalah sebagai berikut: 1. Leads to improve profitability or more positive attitudes toward profit orientation. 2. Improves the job knowledge and skills at all levels of organization. 3. Improves the morale of the work force. 4. Help people identify with organization goals, 5. Help create a better corporate image, 6. Fosters authenticity, openness and trust, 7. Improve the relationship between boss and subordinate, 8 . Aids in organizational development, 9. Learn from trainee, 10. Help prepare guide ness for work, 11. Aids in understanding and carrying out organizational policies, 12. Provides information for future needs in all areas of the organization, 13. Organization gets more effective decision making and problem solving, 14. Aids in development for pro-motion from within, 15. Aids in deve-lopment leadership skill motivation, tojalty, better attitude and other as-pect that successful worker and managers usually display, 16. Aids in in-creasing productivity and or quality of work, 17. Helps keep cost down in many areas, e. g. productions, personal, administration, etc, 18. Deve lops a sense of responsibility to the organization for being competent and knowiedgeable, 19. Improve labormanagement relations, 20 . Reduces outside consulting cost utilizing competent internal consulting, 21. Stimulates preventive management as apposed to putting out fires, 22. Eliminates suboptimal behavior (such for as hiding tools), 23. creates and appropriates climate for growth communication, 24. Aids in improving organizational communication, 25. Help employees adjust to change, 26. Aids in handling confict, thereby helping to prevent stress and tension.

\section{Keuntungan bagi individu}

Keuntungan bagi individu yang juga akan membawa keuntu;ngan bagi lembaga adalah sebagai berikut : 1. Help the individual in making better decisions and effective pro blem solving, 2. Through training and development, motivational, variables of recognition achievement, growth, responsibility and operational zed, 3. Aids in encouraging and achieving self development and self confidence, 4. Help a person handle stress, tension frustration and conflict, 5. 
Provides information for improving lesdership knowledge, 6. Increase job satisfaction and recognition, 7 . Moves a person forward a personal goa's while improving interaction skit, 8. Satisfies personal needs of the trainer (and trainee), 9. Provides trainee for growth and a say in hisher own future, 10. Develops a sense of grouth learning, 11. Help a person develop speaking and bistening skill: also writing skills when exercises are required, 12. Help oiminate in attempting new tasks.

\section{Keumungan dadam hubungan anter individe den kelompok}

Keuntungan dalam hubungan antar individu dan kelompok dalam rangka pelaksanaan kebijakan lembega adalah sebagai berikut. 1. Improve communication between group and individuals, 2. Aids in orientation for new employees and those taking, 3. Provides information on equal opportunity and affirmative action, 4. Provides information on other governmental laws and administrative policies, 5. Improve interpersonal skill, 6. Make organization policies, rules and regulation viable, 7. Build cohesiveness in groups, 8 . Provides a good leaning, growth, and coordination, 9. Make the organization a better place to work and live.

Dari uraian di atas meka jelaslah bahwa orientasi, latihan dan pendidikan yang disebut juga de- ngan pengembangan pegawai mutlak dilaksanakan, apabila lembaga menghendaki efisiensi dan efektivitas penarikan pegawai, bahkan demi keberlanjutan lembaga. Karena aktivitas ini juga merupakan investasi jangka panjang dari lembaga dalam lingkup sumber daya manusia.

\section{Prinsip-Prinsip Latihan Dan Pendidikan}

Agar tujuan latihan dan pendidikan dapat tercapai, hendaknya pelaksanaan latihan dan pendidikan didasarkan pada prinsip-prinsip latihan dan pendidikan. Menurut Yoder dalam Wursanto (2001:61-63) prinsipprinsip latihan dan pendidikan adalah : individuals differences, relation to the job analysis, motivation, active participation, selection of trainees, selection of trainers, trainer training method, and principles of learning. Lebih jelas dapat diuraikan sebagai berikut:

1. Individual Differences

Dalam merencanakan dan melaksanakan latihan dan pendidikan harus tetap diingat, bahwa baik dalam latar belakang pendidikan pengalaman, maupun motivasi peserta sangat bervariasi. Oleh sebab itu baik waktu, sifat dan metode latihan perlu dipertimbangkan baik dalam merencanakan maupun melaksanakannya. Dengan demikian latihan dan pendidikan yang diberikan akan dapat mencapai hasil yang diharapkan. 
2. Relation to the Job Analysis

Lembaga yang akan melaksanakan latihan dan pendidikan bagi pegawainya juga harus memperhatikan analisis jabatan dari lembaganya. Berdasarkan analisis jabatan inilah ditentukan jenis latihan yang diberikan kepada para pegawai. Dengan demikian materi latihan dan pendidikan yang diberikan akan disesuaikan dengan analisis tersebut. Hal ini merupakan sesuatu yang sangat penting, karena bila tanpa ada relevansi program dengan analisis jabatán latihan dan pendidikan yang diberikan akan siasia.

3. Motivation

Latihan dan pendidikan yang - diberikan harus dapat memberikan motivasi pada pesertanya. Tanpa motivasi peserta akan kurang berpartisipasi atau tidak sungguh-sungguh dalam mengikutinya. Sehubungan dengan hal ini maka metode mengajar yang digunakan harus bervariasi, media yang, dipergunakan dipilih yang menarik, serta kesesuaian materi dengan kebutuhan. Semua ini akan memberikan motivasi peserta untuk aktif mengikuti latihan dan pendidikan yang diberikan.

4. Active Participation

Selama latihan dan peiididikan berlangsung para peserta harus aktif mengambil bagian dalam setiap kegiatan. Dalam hal ini melalui latihan dan pendidikan harus dapat memberikan kesempatan untuk saling menyampaikan pendapatnya antara peserta do ngan pelatih. Dalam hal metode penyampaian yang hanya menggunakan ceramah saja akan membosanḳan peserta untuk aktif mengikutinya.

5. Selection of Trainees

Seleksi dalam menentukan pengelompokkan peserta, hal ini diperlukan mengingat adanya perbedaan peserta baik dalam hal la tar belakang pendidikan, pengalaman, maupun keinginannya. Disamping itu seleksi juga dapat menjadi motivasi peserta untuk mengikutinya. Hal ini didasarkan pertimbangan, bahwa pada umumnya individu menganggap bahwa adanya seleksi memberikan kesan hanya orang-orang yang mampu sajalah yang dapat mengikuti latihan dan pendidikan.

6. Selection of Trainers

Seleksi untuk menetapkan individu yang akan memberikan materi pelatihan sangat perlu dilakukan, mengingat tidak setiap individu dapat menjadi pengajar yang baik. Oleh sebab itu pengajar yang akan menyampaikan materi pelatihan harus dipilin individu yang mempunyai kualifikasi sebagai pengajar yang baik. Dalam hal ini diperlukan tenaga pengajar yang telah terdidik, serta 
mempunyai minat dan kesanggupan untuk mengajar. Keefektifan suatu latihan dan pendidikan akan banyak tergantung pada kemampuan dan kesanggupan tenaga pengajarnya.

7. Trainer Training

Di samping seleksi tenaga pengajer atau pelatih, juga para pengajar tersebut sudah harus mondapat pendidikan khusus sebagai pengajar. Sekali lagi hal ini didasarkan pertimbangan batwa tidak semua orang yang mampu dalam bidang tertentu dapat mengajarkan kepandaiannya kepada crang lain.

8. Training Method

Metode pelatihan yang akan digunakan untuk menyampaikan materi pelatihan harus dipilih yang cocok dangan jenis latihan dan pendidikan yang diberikan. Dalam hal ini metode yang diterapkan harus dapat memberiken motivasi peserta untuk selalu berpartisipasi aktif dalam setiap kegiatan.

9. Principles of Leaming

Dalam pelaksanaan latihan dan pendidikan prinsip-prinsip belajar harus mendapatkan perhation. Dalam hal ini pemyempaian materi pelatihan yang sistematis akan memudahkan peserta untuk menerimanya. Pada umumnya individu akan mudah menerima materi yang diberikan dari yang mudah menuju ke yang sukar, atau dari yang sudah diketahui menuju ke hal-hal yang belum diketahui.

\section{Teknik-Teknik}

Latihan

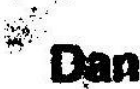

\section{Pendidikan Karyawan}

Program-program latihan dan pendidikan yang selanjutnya lebih dikenal dengan istilah pengembangan, dirancang dalam rangka meningkatkan prestasi kerja, mengurangi absensi dan perputaran, serta memperbaiki kepuasan kerja. Ada dua jenis program latihan dan pengembangan yang sangat dikenal, yaitu: (1) Metode praktis (on the job training), dan (2) Teknik-teknik presentasi informasi dan metode-metode simulasi (of the job training). Masing-masing jenis program latihan dan pengembangan tersebut mempunyai sasaran pengajaran sikap, konsep atau pengetahuan darlatau keterampilan utama yang berbeda. Secara skematik, teknik-teknik latihan dan pengembangan tersebut dapat dilihat sebagai berikut: 
*

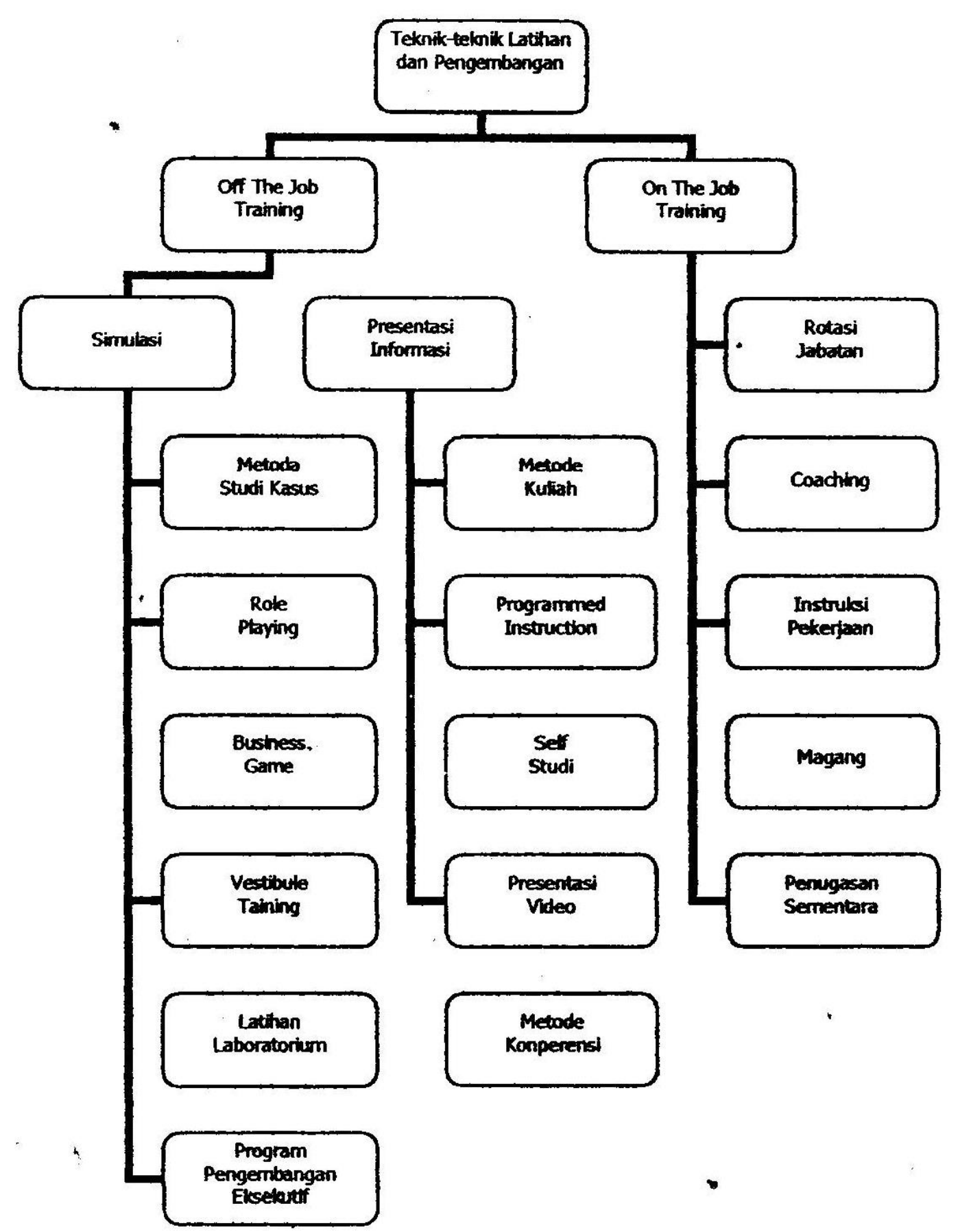

\section{On the job Training}

Teknik-teknik on the job training merupakan metode latihan yang paling banyak digunakan, di mana karyawan dilatih tentang pekerjaan baru dengan supervisi langsung seorang pelatih yang berpengalaman (biasanya karyawan lain). Berbagia macam teknik ini yang biasa digunakan dalam praktik, dijelaskan oleh Hani Handoko (2000:112-116) sebagai berikut : (1) Rotasi Jabatan, pelatihan yang ditujukan untuk memberikan pengetahuan kepada karyawan tentang bagian-bagian organisasi 
yang berbeda dan praktik berbagai macam keterampilan manajerial; (2) Instruksi Pekerjaan, pelatihan yang ditujukan untuk memberikan secara langsung petunjuk pekerjaan, dan digunakan terutama untuk melatih para karyawan tentang cara pelaksanaan perkerjaan; (3) Magang (apprenticeships), merupakan proses belajar dari seorang atau beberapa orang yang lebih berpengalaman. Pelatihan ini sangat tepat untuk pekerjaan yang membutuhkan keterampilan tertentu seperti ahli kerajinan; Coaching, pelatihan yang diberikan oleh penyelia atau atasan kepada karyawan dalam pelaksanaan kerja rutin mereka dalam bentuk bimbingan dan pengarahan; (5) Penugasan Sementara, berupa penempatan karyawan pada posisi manajerial atau sebagai anggota panitia tertentu untuk jangka waktu yeng ditetapkan, di mana karyawan teribat dalam pengambilan kepuusan dan pemecahan masalahmasalah organisasional secara nyata; (6) Sistem Penilaian Pekerjaan, merupakan penilaian yang diberikan kepada karyawan setelah menyelesaikan suatu tugas atau pekerjaan, yang selanjutnya dapat digunakan untuk pengembangan lebih lanjut dari diri karyawan yang bersangkutan.

\section{Off the Job Training}

Teknik-teknik yang termasuk dalam off the job training meliputi: metode-metode simulasi dan presentasi informasi. Pada metode simulasi karyawan peserta latihan menerima representasi tiruan (artificial suatu aspek organisasi den diminta untuk menanggapinya seperti dalam keadaan sebenarnya. Metode silulasi yang umum digunakan meliputi: (1) Metode Studi Kasus, pada metode ini kepada para peserta disediakan deskripsi tertulis suatu situasi pengambilan keputusan, aspek-aspek organisasi terpilih diuraikan pada lembar kasus. Karyawan peserta pelatihan diminta untuk mengidentifikasi masalahmasalah, menganalisis situasi dan merumuskan penyelesaian-penyelesaian altematif. Dengan metode ini dimungkinkan karyawan dapat mengembangkan keterampilan dalam pengambilan keputusan; (2) Role Playing, pada teknik ini peserta pelatihan atau karyawan diminta untuk memainkan berbagai peran yang berbeda. Selanjutnya diminta untuk menanggapi para peserta lain yang berbeda perannya. Tidak disediakan naskah yang mengatur pembicaraaan dan perilaku peserta pelatihan, namun hanya dihadapkan pada suatu situasi yang memerlukan pemecahan masalah. Dengan metode ini dapat mengubah sikap karyawan menjadi lebih toleransi terhadap perbedaan 
\%

individu dan dapat mengembangkan keterampilan antar individu; (3) Business Games, merupakan suatu simulasi pengambilan keputusan dalam skala kecil yang dibuat sesuai dengan situasi kehidupan nyata. Para peserta memainkan game dengan mengambil suatu keputusan tertentu sesuai dengan hati nurani dan berusaha menjelaskan pilihan yang diambil; (4) Vestibule Training, merupakan bentuk pelatihan yang dirancang agar tidak mengganggu kegiatan normal yang terjadi pada lembaga. Bentuk latihan ini dilaksanakan bukan oleh atasan (penyelia), tetapi oleh pelatih-pelatih khusus, dengan mengambil area terpisah dari lembaga tempat pelaksanaan pekerjaan sebenamya, namun pada tempat lafihan tersebut menggunakan fasilitas yang sama persis dengan yang digunakan pada tempat kerja; (5) Laboratory Training, yaitu suatu bentuk latihan kelompok yang terutama digunakan untuk mengambangkan keterampilan-keterampilan antar pribadi. Latihan ini berguna untuk mengembangkan perilaku tanggungjawab terhadap pekerjaan yang menjadi tugasmya; (6) Program Pengembangan Eksekutif, adalah program yang biasanya diselenggarakan oleh lembagalembaga pendidikan seperti universitas, di mana berbagai lembaga atau instansi yang berminat dapat mengirimkan para karyawannya untuk mengikuti paket-paket khusus yang ditawarkan. Kegiatan ini juga dapat dilakukan dalam bentuk kerjasama antara lembaga atau instansi dengan lembaga pendidikan untuk menyelenggarakan kegiatan pendidikan atau pelatihan secara khusus sesuai kebutuhan organisasi.

Sementara itu mengenai teknik-teknik presentasi informasi sebagai upaya untuk mengajarkan sikap, konsep, atau keterampilan kepada peserta pelatihan, dapat dijelaskan sebagai berikut: (1) Kur liah, merupakan suatu metode tradisional dengan kemampuan penyampaian informasi, banyak peserta dan biaya relatif murah; (2) Presentasi Video, teknik ini baisa digunakan sebagai pelengkap bentuk latihan lainnya; (3) Metode Konperensi, metode ini analog dengan bentuk seminar dan merupakan pengganti metode kuliah, di mana proses latihan berorientasi pada diskusi tentang masalah yang telah ditetapkan sebelumnya; (4) Programmed Instruction, metode dengan menggunakan mesin pengajar seperti komputer untuk memperkenalkan kepada peserta topik-topik yang harus dipelajari, dan memerinci serangkaian langkah dengan umpan balik langsung pada penyelesaian suatu langkah: (5) Self Study, teknik ini biasanya menggunakan manual-manual atau 
modul-modul tertulis dan kaset-kaset atau videotape rekaman.

\section{Efektivitas Latihan Dan Pendidik-}

an

Menurut Hamblin dalam Bambeng Suyono (1993:10) efektivitas suatu kegiatan dapat dilihat melalui evaluasi dari kegiatan tersebut. DaInn hal ini masalah yeng berkaitan dengan evaluasi latihan dan pencidikan adalah mengukur seberapa besar latihan dan pendidikan yang cherikan telah menambah, merubah serta meningkatkan pengetahuan. keterampilan dan sikap para peserta sesuai dengan yang diharapkan oleh lembaga.

Senada dengan pendapat teresbut, T. Hani Handoko (200:119) menjelaskan bahwa implementasi deri program latihan dan pengembangan karyawan berfungsi sebagai proses transformasi. Para karyawan yang tidak terlatih diubah menjadi karyawan-karyawan yang berkemampuan, sehingga dapat diberikan tanggung jawab yang lebih besar. Namun demikian untuk mengukur keberhasilan program latihan dan pendidikan, perlu adanya kegiatan evaluasi secara sistematis. Melalui kegiatan evaluasi yang sistematis akan dapat diukur efektivitas dari kegiatan latihan dan pendidikan, bahkan dapat digunakan sebagai bahan penentuan atau pemilihan meiode latihan dan pendidikan yang paling sesuai untuk setiap jenis pekerjaan atau jenjang mannajemen. Langkahlangkah yang dapat dilakukan dalam kegiatan evaluasi adalan: (1) menentukan kriteria evaluasi; (2) melakukan tes pendahuluan (pre test); (3) pelaksanaan pelatihan dan pendidikan; (4) melakukan tes puma pelatihan (post test); (5) transfer ätau promosi terhadap pekerjaan bein; (6) tindak lanjut. Melalui langkahlangkah tersebut pada akhimya akan terukur metode pelatihan yang sesuai dan tujuan pelatihan akan dapat tercapai secara efektif.

\section{PENUTUP}

Langkah awal dan sangat menentukan dalam bidang kepegawaian adalah recruitment pegawai, yang dalam hal ini adalah memilih atau menyeleksi pegawai yang terbaik untuk setiap jabatan dan jenis tugas pada suatu lembaga. Penerimaan pegawai baru pada suatu lembaga tidak dapat menjamin akan diperolehnya pegawai yang siap melaksanakan pekerjaan, karena pada dasarnya tidak ada lembaga pendidikan yang menghasilkan lulusan siap kerja. Demikian juga perputaran karyawan dari satu pekerjaan ke pekerjaan lain atau dari satu baian ke bagian lain, menyebabkan adanya kecanggungan karyawan untuk mengerjakan pekerjaannya di tempat yang baru.

Kegiatan yang dapat menjembatani dua permasalahan tersebut agar karyawan baru atau karyawan 
yang ditempatkan pada tempat baru dapat bekerja sesuai dengan tugasnya adalah latihan dan pendidikan. Kegiatan ini dirancang dalam rangka mempersiapkan pegawai baru, supaya lebih siap melaksanakan pekerjaan, atau diselenggarakan dalam rangka mengembangkan karyawan lama supaya lebih mampu mengembangkan potensinya.

Dalam Undang-undang No. 8 Tahun 1974 tentang Pokok-Pokok Kepegawaian disebutkan adanya dua jenis latihan dan pendidikan pegawai yaitu pre service training (latihan prajabatan) dan in service training (latihan dalam jabatan). Latihan prajabatan adalah suatu latihan yang diberikan kepada pegawai baru agar mereka trampil dalam melaksanakan tugas yang diberikan kepadanya. Sedangkan latihan dalam jabatan adalah suatu latihan yang diberikan kepada pegawai guna meningkatkan keahlian, kemampuan atau ketrampilannya agar diperoleh produktivitas kerja yang tinggi.

Ada beberapa teknik latihan dan pendidikan, namun untuk menentukan teknik yang paling efektif perlu ada penyesuaian-penyesuaian dengan kondisi lembaga penyelenggara. Pada akhirnya harus dilakukan kegiatan evaluasi untuk mengukur efektivitas latihan dan pendidikan tersebut.

\section{Saran}

Menyadari betapa berharganya sumber daya manusia dalam suatu lembaga, maka setiap lembaga harus mampu memperdayakan pegawai yang ada. Terkadang tidak semua pegawai yang ada, siap melaksanakan tugas-tugas yang diberikan, karena belum memperolehnya di lembaga pandidikan sebelumnya, atau karena pegawai sudah merasa cukup dengan kemampuanyang dimiliki. Lama kelamaan hal ini menyebabkan para pegawai tidak bekerja secara optimal, kalau hal ini berkelanjutan akan menyebabkan kerugian bagi lembaga tersebut. Oleh karena itu lembaga harus mengantisipasi lebih awal, dengan menyelenggarakan berbagai jenis pelatihan dan pendidikan untuk pegawai, baik untuk penyegaran maupun melatih kembali keterampilan yang dibutuhkan lembaga.

\section{Daftar Pustaka}

Bambang Suyono, 1993, Mimbar IImu: Efektivitas Latihan dan Pengembangan Pegawai, Malang: Jurnal Pendidikan dan IImu Pengentahuan Sosial.

Hani Handoko, T., 2000, Manajemen Personalia dan Sumberdaya Manusia, Yogyakarta: BPFE

Moekijat, 1989, Administrasi Perkantoran, Bandung: Mandar Maju 
Soedjadi, F.X. 1977, Pokok-Pokok Management Kepegawaian, Jakarta: Lembaga Administrasi Negara.

Undang-undang No. 8 Tahun 1974. Tentang Pokok-Pokok Kepe gawaian. Jakarta.

Winardi, 2000, Kepemimpinan dalam Manajemen, Jakarta: Rineka Cipta

Wursanto, Ig. 2001, Manajemen Kepegawaian 1, Yogyakarta: Kanisius
Yoder, D. 1964. Handbook of Personnel Management and Labour Relation, New York: Long Man

\section{BIODATA:}

Saliman, lahir di Kutasari, Purbalingga, 3 Agustus 1966 adalah lektör pada Program Studi Pendidikan Administrasi Perkentoran, Fakultas IImu Sosial, Universitas Negeri Yogyakarta. 